\title{
DELIVERANCE AND OTHER POEMS
}

\section{Regina Cabato}

Ateneo de Manila University

reginecabato@gmail.com

\section{About the Author}

Regine Cabato is a communication major currently pursuing a minor in Creative Writing at the Ateneo de Manila University. Her poetry has also been published in Under the Storm: An Anthology of Contemporary Philippine Poetry, Philippines Free Press, and Heights. She hails from Zamboanga City. 


\section{Deliverance}

When I first met the artist Tawasil, he narrated

how, as a child, he escaped from Jolo with the beginning of a painting. He recounts: Once we reached the boat, I turned to see Jolo burning. The moral of the story is to never look back. He moved to Zamboanga, and I moved here. I imagine his exodus: the waterlogged signage pointing toward the peninsula, reading "Twenty more miles to the promised land." Until then, nothing to eat but scant milkfish and stale manna. I cruised through my trip: sojourning at gasoline stations and stakeouts where I'd fry my golden calf into quarter-pounders, always looking forward to the next convenience store. I think of how we are always asking for deliverance, how it costs only as much as the next piso fare, how each new country is always over there, an escape from what plagues. I once dreamed that dying is the opposite way: The boats ease toward the shore, and my grandfather extends restored hands. There is an absence of crosses and crescents, only children laughing in the plaza, the whirr of motorboats and Papang beckoning, See, the rest of our lives starts here. A year after I left Zamboanga, I open the television to see Sta. Barbara burning. Already I am brought to a boat clutching a painting, my legs giving way to salt. 


\section{Prayer to St. Maria Goretti, Patron of Chastity}

I walked right into your table; the clay pot at the edge fell. It's all right, you said, it's all right-do you need anything, Alessandro? I wondered how you made me burn even when I did not touch your hair. I told you what I came for. When I took you by the wrist, the dress you were sewing ripped clean down the seam, stitches running like frantic rabbits out their holes. When I thrust the knife, I expected blood and water to spill from your side. The baby began to cry, its shrieking chasing me out of the house. I turned at the doorway: You were swimming in a red sea, on your way out to a great exodus. The thirst in my throat became a drought; I knew then you could not quench me. Later, the doves from the farmhouse down the lane flew out as I heaved it open. This was where they found me, the pools of gathered rainwater reflecting the beams, disturbed only by the feet of policemen. Today, the stoup is clear. Outside, rain beats steadily, assigning tears to the figures on stained glass. You are standing at the entrance with a box of offerings. The doves treat the rafts as pews. I kneel at this altar below them, and there are lilies burning in my hands. 


\section{Mambabatok}

Arms covered in armor, she plucks patterns from herself and draws on my arm with soot and water. She gives me dragon scales for bravery. Steady hands pin new skin on me with bamboo and a thorn. I settle into my plates, not too different from hers: chila, or the python. It burns, leaving a trail of ash in its wake. I think of a rhyme: Ashes to ashes we all fall-

Down her wrist is a name. I wonder whose it is, whether he is here. She answers my question in a glance; gone, she says, like all of us soon. But she cannot be erased. I see her already in her granddaughter as she inks a foreigner who receives the $u f o g$, honeycomb, for fertility. When I remember dragons no longer exist, I tell myself they were brave. 